\title{
Contextualising Bickerton's Wainoni
}

Julia Gatley, School of Architecture \& Planning, University of Auckland, Auckland

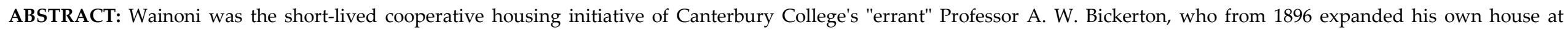

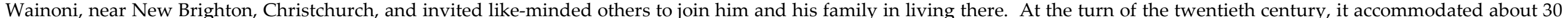

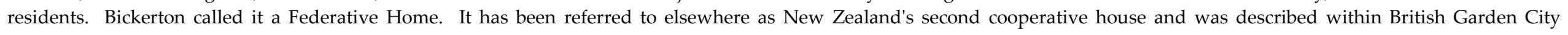

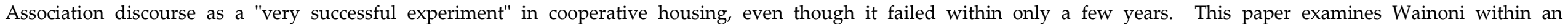

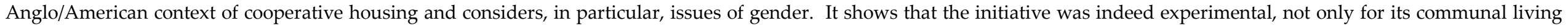

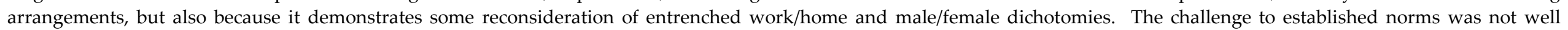
received locally, in part because it was embedded within a broader critique of the institution of marriage.

Within garden city and garden suburb scholarship, architect $\mathrm{H}$ Clapham Lander is reasonably well known, particularly for the design of Homesgarth (1909-13) at Letchworth Garden City, north of London. Homesgarth was the British garden city movement's first "cooperative quadrangle," i.e. its first medium-density scheme combining private residential accommodation in conjunction with communal kitchens and dining halls. Ebenezer Howard and his wife lived at Homesgarth from 1913, ${ }^{1}$ confirming that the initiator of the garden city movement was not only an admirer and supporter of cooperate housing, but also an active participant in it.

\footnotetext{
${ }^{1}$ See Hayden Grand Domestic Revolution pp 230-237. For a more detailed history of British cooperative initiatives, see Pearson The Architectural and Social History of
} Cooperative Living.
Less known is the fact that Lander knew of Professor AW Bickerton's "Federative Home," Wainoni, near New Brighton, Christchurch, before designing Homesgarth. He discussed Wainoni at some length in a paper that he presented at the Garden City Association's Bournville conference in 1901. At that time, he described it as a "very successful experiment" in cooperative housing. ${ }^{2}$

He could describe Wainoni as an "experiment" because at the turn of the twentieth century, the single-family home was entrenched as "a stronghold of traditional values," the "home of the virtuous citizen," and "the basis of a stable society." 3 The ideal family home would be

\footnotetext{
${ }^{2}$ Lander "The Advantages of Co-operative Dwellings" pp 66-67.

3 Wright Moralism and the Model Home p 9. For a
} discussion of the emergence of these ideas in early three-bedroomed, with separate bedrooms for parents, boys and girls. John Ruskin had been an influential proponent internationally, linking morality and family values to the home. ${ }^{4}$ So too were Frances Willard and the Women's Christian Temperance Union, which took as its motto "For God, Home and Humanity," and emphasised women's duty to uphold the values associated with the home and, indeed, "to make the whole world Homelike." 5 Alternatives to the single-family home were often perceived as radical and, indeed, experimental.

So an experiment, yes, but a "very successful experiment"? It is difficult today to think of

nineteenth century Britain, see Davidoff and Hall Family Fortunes.

${ }^{4}$ Wright Moralism and the Model Home pp 12-14.

${ }^{5}$ Quoted in Wright Moralism and the Model Home $\mathrm{p} 105$. 
Wainoni as "very successful," in part because it failed within only a few years (financial reasons were cited) and also because it seems to have disappeared from the New Zealand literature on architecture, town planning and housing almost as quickly. For example, at the First New Zealand Town Planning Conference, held in Wellington in 1919, ${ }^{6}$ various delegates made reference to the benefits of cooperation, including the Christchurch architect Samuel Hurst Seager, who advocated cooperative farming for small landholders; ${ }^{7}$ the Whanganui, later Auckland, architect Reginald Ford, who focused attention on cooperative housing and cited Homesgarth as an example of such a scheme; 8 and several of the female delegates spoke about cooperative housekeeping, kitchens, dining facilities, laundries and child care in greater detail. Like Seager and Ford, the women cited overseas examples. ${ }^{9}$ No-one mentioned Wainoni. It seems likely that the Canterbury delegates at least would have

\footnotetext{
${ }^{6}$ See Gatley "Sex and the Slum."

7 Seager "The Garden City" pp 120-122.

${ }^{8}$ See Ford "Paper on 'Garden Suburbs'" p 149.

${ }^{9}$ Mrs M Irwin, for example, who was French, suggested a Europeanisation of New Zealand cities, including municipally controlled markets in front of town halls or cathedrals. See Irwin, "Comments" pp 152-153.
}

remembered Bickerton's Federative Home for the reason that it had maintained a high profile in the local press during the short time it was in operation. They would also, however, have remembered both that it had failed, and that prior to failing it had gained a reputation for "free love," neither of which would have strengthened the case for increased cooperation in 1919.

Bickerton is the subject of a biography by historian RM Burdon (1956) and Wainoni is the subject of both a refereed journal article by Australian academic Bill Metcalf (2004) and an illustrated book by Christchurch real estate agent Tim Baker (2004). ${ }^{10}$ I have trawled through the Christchurch records myself and have not been able to add to the story of Wainoni as constructed by Burdon, Metcalf and Baker. I understand that additional records are held at the Carter Observatory in Wellington, but have not yet had the opportunity to investigate these myself. I expect that they would relate primarily to Bickerton's scientific research rather than to his personal and domestic life.

${ }^{10}$ Burdon Scholar Errant, Metcalf "Federative Home" pp 25-46, Baker Professor Bickerton's Wainoni.
This paper differs from the work undertaken by others in that it considers Wainoni within an Anglo/American context of cooperative housing and explores gender issues. Comparison with the British garden city initiatives is particularly relevant, not only because Lander knew of Wainoni, but also because Wainoni and the British garden city examples were initiated by men, whereas some of the contemporaneous American schemes were initiated by women and demonstrate quite different motivations.

This is not to suggest that cooperation was first developed within the garden city movement or, indeed, at the turn of the twentieth century. Two earlier figures who were extremely influential upon the growth of communitarian ideas throughout the Western world were the Welshman, Robert Owen (1771-1858) and the Frenchman, Charles Fourier (1772-1837). They initiated and inspired the first cooperative housing experiments in the first half of the nineteenth century. The early initiatives were generally developed in reaction against the congestion and squalor of newly industrialised cities. As the nineteenth century progressed, communitarian initiatives were often premised less on creating an alterative to 
congestion and squalor, and more on the "servant problem," domestic efficiency and the issue of women's work.

Secondary sources on British and American cooperative housing initiatives provide precedents for asking feminist questions of Wainoni. Was Wainoni premised on increasing the efficiency with which cooking, cleaning and childrearing could be performed and thus reducing the workload of women/housewives? To what extent were the men resident at Wainoni expected to make contributions in each of these areas? Should Bickerton be described as a feminist? Rumours of "free love" at Wainoni and then Bickerton's departure from not only Christchurch but, indeed, New Zealand and his wife and children in 1910 provide additional layers of complexity.

\section{Bickerton and Wainoni: An Introduction}

Alexander William Bickerton (1842-1929), a professor of chemistry at Canterbury College, has a reputation that precedes him. It is expressed in the title of Burdon's 1956 biography of Bickerton, Scholar Errant, ${ }^{11}$ and in the subheading of the more recent

\footnotetext{
${ }^{11}$ Burdon Scholar Errant.
}

Dictionary of New Zealand Biography entry on him: "Scientist, university professor, eccentric."12 I defer to Burdon's sleeve-notes:

The Eccentric Professors of popular fiction might well have been inspired by Alexander William Bickerton, first professor at Canterbury College. He arrived in New Zealand in 1874 and soon startled the staid young province of Canterbury with his unorthodox ideas and equally unconventional behaviour. His emphatic disapproval of marriage as an institution shocked the moralists, while his experiment in communal living the "Federative Home" at Wainoni - was regarded as extreme socialism and an excuse for sexual promiscuity. Yet, in chemistry and physics "Bicky" was a brilliant teacher, and his most famous pupil, Sir Ernest Rutherford, always regarded him with admiration and affection. ${ }^{13}$

From 1884, Bickerton lived in the New Brighton sandhills, in a house built for him and his family. Photographs show it to be a sizeable single storey villa. ${ }^{14}$ From 1896, with a view to inviting like-minded others to join him and his family in living at Wainoni, he began expanding the facilities at his house by adding small outbuildings. To do this cheaply, he developed his own building

12 Parton "Bickerton, Alexander William."

${ }^{13}$ Burdon Scholar Errant sleeve-notes.

14 Photographs were published in "A Federative Home" p 30, and republished in Baker Professor Bickerton's Wainoni. technology. It involved timber framing, clad and lined with paper onto which a thick tar had been applied. ${ }^{15}$

Bickerton launched the Federative Home in the spring of 1898 . Burdon suggests that Bickerton would have envisioned the home as a kind of sociological experiment and that New Zealand's reputation as the world's "social laboratory" would have made this country seem all the more ripe for this experiment in "sociological reform." ${ }^{16}$ The experiment did not, at this stage, extend to collective ownership.

By 1899, Wainoni had about 30 residents. ${ }^{17}$ Some had outside jobs and others worked in the Home's fireworks factory. Within a short time, pine trees were planted, a nursery and kindergarten were added, then an aquarium and an art gallery, and art classes were started. All domestic work was done cooperatively, with tasks being allocated where possible according to personal preference: "Our domestic duties are discharged on the principle that everybody

\footnotetext{
${ }^{15}$ Burdon Scholar Errant p 69.

${ }^{16}$ Burdon Scholar Errant p 67.

${ }^{17}$ Burdon Scholar Errant p 70.
} 
should do whatever he or she likes best."18 Bickerton's own task was to light the fires in the main building each morning.

Bickerton had hoped for 100 residents at Wainoni, but the number never rose much above 30 - and this figure included two of the Bickertons' sons, along with their wives and children. ${ }^{19}$ But more than this, some of the residents took advantage of Bickerton and the Wainoni facilities, neither paying rent nor contributing to the domestic work. They were described as "freeloaders." Thus, after only a few years, Bickerton realised his project was a financial failure. In addition, it had developed a reputation for "free love." This resulted not only from the communal arrangements, but also from Bickerton's critiques of the institution of marriage, published both in his book The Romance of the Earth (1898), and elsewhere, for example in a letter, "The Morality of Marriage," to the editor of a local newspaper (1899), which stimulated heated debate between those for and against the institution. ${ }^{20}$

${ }^{18}$ Bickerton quoted in "Wainoni: A Federative Home" $\mathrm{p}$ 3.

${ }^{19}$ Burdon Scholar Errant p 97.

${ }^{20}$ Burdon Scholar Errant pp 70-73.
In the face of financial failure, rumour and speculation, Bickerton was close to a nervous breakdown. He took a year's leave of absence from the university, spending 1900 in England. His employment at the university was tenuous through this period, and shortly after his return to Christchurch he was dismissed. It was a stressful time and Bickerton wound up the Federative Home in 1903. ${ }^{21}$ He then turned Wainoni into an amusement park, with merry-go-rounds and stalls. Though it was an initial success, by 1910 the amusement park too was failing. With financial support from his allies, Bickerton moved back to Britain that year, to lecture and promote the publication of his scientific research, leaving his wife, Phoebe, and their sons living in the Wainoni home.22 Phoebe died in 1919. Bickerton invited an old friend from Christchurch to join him in London, to serve as his housekeeper, secretary and general helper. She arrived in mid 1920 They married almost immediately and were, by all accounts, deliriously in love and happy together. ${ }^{23}$

\footnotetext{
${ }^{21}$ Metcalf "Federative Home" p 37; and Baker Professor Bickerton's Wainoni sleeve-notes.

${ }^{22}$ Burdon Scholar Errant pp 98-103.

${ }^{23}$ Burdon Scholar Errant p 131.
}

\section{Wainoni and the Garden City Association, Britain}

Ebenezer Howard, Raymond Unwin, George Cadbury and other well known figures of the garden city movement presented papers at the Garden City Conference at Bournville in September 1901. Of these, it is Lander's paper, "The Advantages of Co-operative Dwellings," that is of interest to me here, as a result of its description and, indeed, praise of Wainoni and its demonstration that Howard, Unwin and others were not only aware of the Christchurch initiative, but understood it to have been a success, before pursuing their own cooperative initiatives within their garden city and suburb schemes.

In his paper, Lander claimed that: "Cooperation has been the watchword of the latter half of the nineteenth century." 24 For the most part, he spoke in general rather than specific terms, and he identified his British examples only vaguely. This was his first:

A more modern attempt has been made in the west of London to put the ideas of Co-operation into practice. The plan there suggested is to be rectangular with a

${ }^{24}$ Lander "The Advantages of Co-operative Dwellings" $\mathrm{p}$ 61 
square garden in the centre. ${ }^{25}$

His second example was slightly more specific: "Another example of a very different character is afforded by the Rowton Houses, of which several have been built in London."26 Then suddenly, with his third and final example, he was explicit: "A very successful experiment of this description is being conducted by Professor Bickerton and his friends at Wainoni, in New Zealand."27

Lander went on to explain that Bickerton had made his own home cooperative by adding outbuildings for others to live in; that the communal facilities - drawing room, dining room, social hall - were contained within Bickerton's original house; that most residents were in paid employment rather than working off the Wainoni land; that a small number of servants were still employed (but, it was hoped, not for much longer); that food was purchased wholesale for all residents; that a new detached kitchen had been erected; and

${ }^{25}$ Lander "The Advantages of Co-operative Dwellings" p 66.

${ }^{26}$ Lander "The Advantages of Co-operative Dwellings" $\mathrm{p}$ 66.

${ }^{27}$ Lander "The Advantages of Co-operative Dwellings" p 66. that meals were eaten communally, with breakfast served from 7.30 to $9.00 \mathrm{am}$., lunch at 12 noon, and dinner at $6.00 \mathrm{pm} .{ }^{28}$

Lander noted Bickerton's conviction that a cooperative house needed 100 residents or more in order to be financially viable. He also made the claim that at Wainoni, "The number of residents is now considerably over one hundred." 29 The source for this latter piece of information is not known, but it is not consistent with the records of Wainoni and the documented figure of $30 . .^{30}$ This overblown figure alone could have led Lander to conclude that Wainoni was a "very successful experiment."31

\footnotetext{
${ }^{28}$ Lander "The Advantages of Co-operative Dwellings" pp 66-67.

${ }^{29}$ Lander "The Advantages of Co-operative Dwellings" $p$ 66.

30 "Wainoni: A Federative Home" p 3.

${ }^{31}$ Lander's comment that it was hoped that servants would soon be dispensed with proved correct. Within a matter of months, it was reported that: "At the present time, the whole of the household work is carried on by the "federators." We do not employ any servants whatever. ... When the servants left many months ago, we had one meeting to talk over the arrangements Since that was held, everything has been done by mutual consent." Bickerton quoted in "Wainoni: A Federative Home" p 3.
}

Several years after the Bournville conference, as we have seen, Howard, with Parker and Unwin, developed the "cooperative quadrangle," with Lander's Homesgarth being the first and best-known example. ${ }^{32}$ It was followed by Meadow Way Green, Letchworth (1915-24) and Guessons Court, Welwyn (1922). The British examples bore no resemblance to Wainoni in planning and design, the New Zealand forerunner being a timber house with outbuildings, sited on a large piece of land outside of Christchurch, and the British quadrangles being medium density schemes in urban areas.

It is worth pausing here to consider the scholarship on Britain's early twentiethcentury cooperative housing initiatives, because it provides a useful precedent for asking feminist questions of Wainoni. In particular, historian Helen Meller has considered the issue of gender within the British schemes, and the embedded metaphorical separation of men and women into "separate spheres." She showed that the idea of separate spheres was accepted and

\footnotetext{
32 See Hayden Grand Domestic Revolution pp 230-237. For a more detailed history of British cooperative initiatives, see Pearson Architectural and Social History of Cooperative
} Living. 
even reinforced by early twentieth-century British town planning advocates including Howard, Unwin and Patrick Geddes and by their disciples including Lewis Mumford. ${ }^{33}$ Meller noted that HG Wells criticised the original plans of Letchworth for making no provision for liberating women from their domestic role. She also suggested that while Homesgarth was a response to such criticisms, it was not a financial success and it "did not fit the cultural context of Edwardian society."34 Further, and importantly, while Howard provided these opportunities for communal housekeeping, he did not suggest that men might contribute to the domestic work.

Iain Borden has examined Homesgarth in more detail. He identified advantages for both middle-class women and their servants in this scheme's provision of servants' quarters that were separate from their employees' homes, but his overall conclusions were aligned with Meller's:

The lives of the Homesgarth women were defined and controlled by men: they were neither to be allowed to earn their own living, nor to be paid a wage in recognition of housework as a socially necessary form of

\footnotetext{
${ }^{33}$ See Meller "Planning Theory" pp 85-98.

${ }^{34}$ Meller "Planning Theory" p 86.
}

labor. Despite claims to the contrary, middle-class Garden City cooperative living allowed little escape from the realms of economic and cultural restrictions. ${ }^{35}$

Clara Greed too has suggested that: "like many middle-class men he (Howard) was probably more concerned with dealing with the servant problem than with restructuring home/work, male/female dichotomies."36

Patrick Geddes was more overt in encouraging the perpetuation of the two spheres. In his books, including The Evolution of Sex (1898) and Cities in Evolution (1915), he discussed men's and women's differing social roles in terms of biological differences. He emphasised women's altruism and desire to nurture and the positive impact of such qualities on the evolution of the race. $\mathrm{He}$ identified "Homes" (with a capital $\mathrm{H}$ ) as significant in this regard too: "For the individual and family, street and village, for town and city, even for state and empire, what better can we invest in, than in Homes?"37 Thus Meller could conclude that in the planned cities and towns of this period, the

\footnotetext{
${ }^{35}$ Borden "Social Space" p 253.

${ }^{36}$ Greed Women and Planning p 94. Note: my brackets.

37 Geddes Reports on the Towns in the Madras Presidency Visited by Professor Geddes 1914-15 (1915): 96, quoted in Meller "Planning Theory" p 94.
}

division of roles according to sex was to be perpetuated and even reinforced. ${ }^{38}$ Public/private and male/female dichotomies, and thus the subordination of women, were central to mainstream town planning discourse.

But men were not alone in perpetuating the division of roles and thus women's domesticity. Alison Ravetz has examined women's input into house design in late nineteenth and early/mid twentieth-century Britain through the ideas of reformers including Octavia Hill and Henrietta Barnett and women's contributions to government research on house design including the Women's Subcommittee of the Ministry of Reconstruction formed in the latter stages of World War I and submissions to Raymond Unwin's Tudor Walters Report (1918). Ravetz concluded "that women themselves agreed that houses should be designed for housewives." 39 The reformers and

${ }^{38}$ Meller "Planning Theory" p 96. Greed agrees that "in mainstream British town planning, importance was generally given to domestic ideology which emphasized the formation of individual, exclusive households, with the man as breadwinner and the wife as homemaker." See Greed Women and Planning p 105.

${ }^{39}$ Ravetz "A View from the Interior" p 200. 
campaigners were preoccupied with the working-class housewife and aimed to "provide houses that would enable workingclass mothers to rear healthy families and perform their housework more efficiently." 40 Working-class women simply wanted adequate space, privacy and the basic services. These they could adapt to suit their families' changing needs. In particular, working-class women tended to oppose the imposition of communal arrangements upon them and favoured instead increased privacy in their own homes. ${ }^{41}$ There may have been some working-class idealisation of middleclass life in this aspiration to middle-class norms.

Scholars agree, then, that the overriding concern of these British housing reformers and town planning advocates, in relation to cooperative housing, was to find a way to overcome the servant shortage, which was increasingly apparent as more and more young working-class women chose to work in factories rather than in domestic service (factory hours were shorter and the pay better). Thus, within the garden city

\footnotetext{
${ }^{40}$ Ravetz "A View from the Interior" p 200.

${ }^{41}$ Ravetz "A View from the Interior" pp 196, 202.
}

movement at least, cooperation was premised on increasing the efficiency with which cooking, cleaning and childrearing could be performed, in order to make it manageable for housewives with either fewer servants or no servants at all. Even in the cooperative environment, however, domestic work would remain women's work. Meller summarises this thus: "the men tended the gardens while the women processed the produce and arranged the flowers. In all important aspects, the garden city ideal reinforced the concept of the two spheres." 42

\section{Bickerton's Motivations}

In late nineteenth-century New Zealand, servants were already in short supply: most New Zealand women did their own housework. Charlotte Macdonald concludes

\footnotetext{
42 Meller "Planning Theory" p 93. Meryl Aldridge presents a different view. She suggests that Howard gave men and women equal status by allowing members of both sexes to be elected to the Boards of Management that he proposed would run garden cities. Aldridge also notes that women joined the Garden City Association to promote Howard's Utopian vision and within the Association made several attempts to organise a Women's League. Further, Letchworth women wore loose dresses and sandals and went hatless and in doing so were embracing the symbols of social change. See Aldridge "Only Demi-Paradise?" p 25.
}

that "'doing without help" became not only the norm but a matter of pride for all but a small élite." ${ }^{43}$ This is evident in our housing stock from this period: thousands of villas were built for small households without servants. Housework was changing with the replacement of wood stoves with gas appliances from the turn of the century and the domestic use of electricity, but laundry in particular remained arduous, particularly for families with large numbers of children.

As mentioned, at Wainoni, all domestic work was done cooperatively, with tasks being allocated where possible according to personal preference, and Bickerton's own task was to light the fires in the main building each morning. That the sharing of domestic duties among a larger number of people would eliminate "doubling-up" on individual tasks, and thus lead to increased domestic efficiency, was without doubt part of his rationale in establishing the cooperative house.

Wainoni differed from the British examples, however, in that Bickerton had an additional concern: the institution of marriage, to which he was strongly opposed. He believed that

\footnotetext{
${ }^{43}$ Macdonald "Strangers at the Hearth" p 56.
} 
marriage meant men's ownership of women and that this resulted in "unwanted maternity" and, as a consequence, "racial deterioration" (to use the parlance of the day); whereas if women were having children consistent with their love and their passion, rather than as bound by law, then their sexual selection would be guided by their intuitive, subconscious ("natural") desire for "racial improvement." "If at liberty to do so women would choose only the noblest men to be fathers of their children." 44 Bickerton believed that women should be able to choose their sexual partner/s without needing to take into consideration any potential partner's financial security or social standing. Further, he described continued co-habitation by couples who no longer loved each other as "immoral."45

It seems that these views were not a consequence of any bad experience within his own marriage. Burdon asserts that: "For fifty years he [Bickerton] lived happily with the wife of his choice, and long after her death he married a second time. No shadow of discord ever clouded his own domestic life."46 $\mathrm{He}$

${ }^{44}$ Burdon Scholar Errant p 68.

${ }^{45}$ Burdon Scholar Errant p 72.

${ }^{46}$ Burdon Scholar Errant p 70. then married a second time, in the year following his first wife's death. He did, however, confess to witnessing a "sex tragedy" at the age of 20, the details of which were not explained, and to having been aware of terrible domestic situations that some others were forced to endure. ${ }^{47}$

In Bickerton's view, then, communal living arrangements would provide the conditions in which alternatives to the institution of marriage could be pursued. His book, The Romance of the Earth, was published the same year that Wainoni was launched as a cooperative house. His radical ideas about marriage, and the extent to which they were published, drew attention to this one aspect of Wainoni at the expense of others, fuelling the rumours of "free love" and encouraging Christchurch and Lyttelton's moral majorities to judge it on the basis of the ideas and the rumours rather than on any particular evidence or documentation. Today Bickerton's descendents continue to dismiss the rumours of "free love" as unfounded. ${ }^{48}$

${ }^{47}$ Burdon Scholar Errant p 71.

${ }^{48}$ Bickerton "Wainoni Commune" p A10.
More Radical Still: Feminist Initiatives in the US

More radical again were the alternative domestic arrangements being explored by some American feminists in the 1890s and the opening years of the twentieth century. Described as material feminists by Dolores Hayden, ${ }^{49}$ these individuals interpreted women's domestic labour as a form of economic exploitation, located it at the root of women's inequality and campaigned for its socialisation. Their concern extended to both wives who worked in the home for no pay and domestic servants who worked long hours for little pay. They demanded honour, respect and remuneration for women's domestic work. Further, in the tradition of Robert Owen and Charles Fourier, they developed schemes that incorporated cooperative housekeeping, kitchens, dining facilities, laundries and child care, resulting in proposals that transformed the design of homes, neighbourhoods and cities. Their schemes included kitchenless apartments and grouped kitchenless houses in combination with a variety of communal facilities.

\footnotetext{
${ }^{49}$ See Hayden Grand Domestic Revolution.
} 
In Melusina Fay Peirce's original conception of cooperative housekeeping, women performed domestic work communally, with breadwinning husbands paying the women for their work. ${ }^{50}$ This freed up women's time, enabling them to choose between developing their careers or, if they had children, spending more time with them. Hayden differentiates between subsequent cooperative housing schemes intended to accommodate educated and professional women, which required poorer women to be employed to cook and clean for them, wash their laundry and mind their children, ${ }^{51}$ and those schemes aimed at poorer women, where each would contribute to the communal cooking, cleaning, laundry and child care and would receive time off when others were performing the work. ${ }^{52}$ The schemes for professional women were a

${ }^{50}$ Hayden Grand Domestic Revolution p 68.

51 The Evanston Cooperative Housekeeping Association's 1890 experiment in cooperative laundry and cooked food delivery was a middle-class initiative that failed because of class conflict. Servants lost their jobs in this attempt to achieve increased efficiency. See Hayden Grand Domestic Revolution pp 215-219.

52 Jane Addams was significant and influential in this regard, encouraging poor women to live cooperatively at the Jane Club, established in 1898 in conjunction with Hull-House. See Hayden Grand Domestic Revolution pp 153-155, 168-170. response to the increasing shortage of domestic servants and the desire for increased domestic efficiency; the schemes for poorer women were a more direct response to the exploitation of women's domestic labour and the desire to liberate women from domestic work.

Hayden concludes that these cooperative initiatives were increasingly at odds with the mass media's rhetoric of consumption. ${ }^{53}$ Further, after the Russian Revolution there was much "red-baiting" of feminists and socialists in the United States. According to Hayden, this and the Hoover Commission Report on Building and Home Ownership (1931) together put an end to the material feminists' campaigns. The Hoover Report advocated single-family home ownership and contributed to the realisation of the 50 million such homes that housed three-quarters of American families. ${ }^{54}$ Home ownership was thought to discourage strikes and to foster conservatism and social order. In addition to being anti-socialist, the detached suburban house was anti-feminist, confirmed by

${ }^{53}$ Hayden Grand Domestic Revolution pp 22-23, 274-275. ${ }^{54}$ Hayden Grand Domestic Revolution p 10. maxims such as "A woman's place is in the home" and "A woman's work is never done."

\section{Conclusions}

Wainoni has been identified as New Zealand's second cooperative house. ${ }^{55}$ It appears that Root's Assembly, a Brethren community that settled in Fielding in 1874, was the first. ${ }^{56}$ If indeed Wainoni was the second, it was still both experimental and radical at the national level. It was more aligned with the British garden city initiatives that were instigated by men than it was with period American schemes conceptualised and pursued by women. But it differed from the British examples in a significant way. Bickerton took the task of lighting the fires in the main building in the mornings. The individual domestic duties of others are not documented, but on the basis of Bickerton performing a duty himself, and his comment that, "Our domestic duties are discharged on the principle that everybody should do whatever he or she likes best," 57 it seems reasonable to suggest that all residents, not just the women, were expected to contribute to the domestic work. With this male contribution to

${ }^{55}$ Baker Professor Bickerton's Wainoni sleeve-notes.

${ }^{56}$ Metcalf "Intentional Communities" p 705.

${ }^{57}$ Bickerton quoted in "Wainoni: A Federative Home." 
domestic work, Wainoni demonstrates some reconsideration of entrenched male/female dichotomies. There was also reconsideration of the work/home dichotomy, in that it was acceptable for residents - presumably both men and women - to choose to work in outside jobs while paying to live at Wainoni, or to work on site and to live there for free. Bickerton's challenge to gendered norms is demonstrated more overtly by his attitude towards marriage. He was not interested in creating an environment that would constrain women within established norms. To the contrary, he created an environment in which alternatives to the institution of marriage could potentially be pursued. The extent to which they were pursued was the subject of speculation and gossip, but remains undocumented and thus unknown at the present time.

Bickerton left it to others to focus more explicitly on the shortage of servants and to develop initiatives that were more specifically aimed at easing women's onerous domestic workload. For example, domestic training for girls was introduced early in the twentieth century. ${ }^{58}$ A School of Home Science was opened at the University of Otago in 1911. The Housewives' Union was also formed that year, to organise cooperative buying for housewives. It was often the case that these initiatives were aimed at supporting women in their roles as housewives and mothers, rather than challenging assumptions about women's domesticity. Domestic training in particular reinforced the idea of the separate spheres and the assumed path that women's lives should follow. Given the more mainstream support for increased domestic efficiency, it is reasonable to suggest that had Wainoni been premised more upon the "servant problem," and less upon Bickerton's controversial critique of marriage, it might have been more socially acceptable and thus more appealing to a greater number of people.

${ }^{58}$ Nolan Breadwinning pp 103-136. 


\section{REFERENCES}

Aldridge, Meryl "Only Demi-Paradise? Women in Garden Cities and New Towns" Planning Perspectives (1996) 11:24-25.

Baker, Timothy David Professor Bickerton's Wainoni Christchurch: s.p., 2004.

Bickerton, Alexander William The Romance of the Earth (Christchurch, N.Z.: Bickerton Brothers, [1898])

Bickerton, B.W. "Wainoni Commune" Press (7 December 2002):A10.

Borden, Iain "Social Space and Cooperative Housekeeping in the English Garden City" Journal of Architectural and Planning Research (Autumn 1999) 16(3):242-257.

Burdon, R M Scholar Errant: A Biography of Professor A. W. Bickerton Christchurch: Pegasus Press, 1956.

Davidoff, Leonore and Catherine Hall Family Fortunes: Men and Women of the English Middle Class, 1780-1850 London: Hutchinson, 1987.

"A Federative Home, Wainoni" Lyttelton Times (5 April 1899) 30, and illustrated supplement.

Ford, C Reginald "Paper on 'Garden Suburbs'" Official Volume of Proceedings of the First New Zealand Town-planning Conference and Exhibition Wellington: Government Printer, 1919:139-149.

Gatley, Julia "Sex and the Slum: Imperialism and Gender in Nascent Town Planning, Australia and New Zealand, 1914-1919" PhD thesis, The University of Melbourne, 2003.

Geddes, Patrick Cities in Evolution (London: Williams \& Norgate, 1915)

Geddes, Patrick The Evolution of Sex (London: Walter Scott, 1898)

Greed, Clara H Women and Planning: Creating Gendered Realities London and New York: Routledge, 1994.

Hayden, Dolores The Grand Domestic Revolution: A History of Feminist Designs for American Homes, Neighborhoods, and Cities Cambridge, Massachusetts: MIT Press, 1981.
Irwin, Mrs M "Comments," Official Volume of Proceedings of the First New Zealand Town-planning Conference and Exhibition Wellington: Government Printer, 1919:152-153.

Lander, H Clapham "The Advantage of Co-operative Dwellings" The Garden City Conference at Bournville: Report of Proceedings including Papers and Speeches London: Garden Cities Association, 1901.

Macdonald, Charlotte "Strangers at the Hearth: The Eclipse of Domestic Service in New Zealand Homes, c. 1830s-1940s" ed. Barbara Brookes At Home in New Zealand: Houses History People Wellington: Bridget Williams Books, 2000: 41-56.

Meller, Helen "Planning Theory and Women's Role in the City" Urban History Yearbook (1990) 17:85-98.

"The Morality of Marriage [Letter to the Editor]" Lyttelton Times (6th March 1899)

Nolan, Melanie Breadwinning: New Zealand Women and the State Christchurch: Canterbury University Press, 2000.

Metcalf, William "Federative Home" Communal Societies (2004) (24):25-46.

Metcalf, William "Intentional Communities: Australia and New Zealand" eds Karen Christensen and David Levinson. Encyclopedia of Community: From the Village to the Virtual World Thousand Oaks, California: Sage Publications, ca. 2003.

Official Volume of Proceedings of the First New Zealand Town-planning Conference and Exhibition. Wellington, 20-23 May 1919 Wellington: Government Printer, 1919.

Parton, H N "Bickerton, Alexander William 1842-1929" Dictionary of New Zealand Biography, updated 22 June 2007, URL: http://www.dnzb.govt.nz/.

Pearson, Lynn F The Architectural and Social History of Cooperative Living Basingstoke and London: Macmillan Press, 1988. 
Pearson, Lynn F "Cooperative Housekeeping" Planning History Bulletin (1984) 6(2):33-41.

Ravetz, Alison "A View from the Interior" Judy Attfield and Pat Kirkham (eds) A View from the Interior: Feminism, Women and Design London: Women's Press, 1989:187-205.

Seager, S Hurst "The Garden City in Relation to the Reconstruction and Repatriation Problems" Official Volume of Proceedings of the First New Zealand Town-planning Conference and Exhibition Wellington: Government Printer, 1919:115-126.

[Unwin, Raymond] "[Tudor-Walters] Report of the committee appointed by the president of the local government board and the Secretary for Scotland to consider questions of building construction in connection with the provision of dwellings for the working classes in England and Wales and Scotland, and report upon methods of securing economy and despatch in the provision of such dwellings" (1981), ref: D/EDN/E2, National Archives of the United Kingdom.

"Wainoni: A Federative Home" Lyttelton Times (17 February 1902) 3.

Wright, Gwendolyn Moralism and the Model Home: Domestic Architecture and Cultural Conflict in Chicago, 1873-1913 Chicago and London: University of Chicago Press, 1980. 